\title{
AN OVERVIEW OF THE NEW COMPETITION LAW: ISSUES FOR THE OIL AND GAS INDUSTRY
}

\author{
LAWSON A.W. HUNTER, Q.C.* AND JOHN F. BLAKNEY**
}

This paper reviews the major changes to Canada's competition law enacted in 1986, including new merger and abuse of dominant position provisions, the establishment of a Competition Tribunal, mandatory pre-notification of certain transactions, and revisions of the prohibition against agreements in restraint of trade. Special attention is given to joint ventures, export agreements and vertically integrated resource companies.

\section{INTRODUCTION}

On June 19, 1986, Royal Assent was given to a major revision in federal competition law. The Competition Tribunal Act establishing a new Competition Tribunal to review restrictive trade practices was proclaimed in force on that date, as were significant amendments to the Combines Investigation Act (referred to herein as the Combines Act), which has been restyled the Competition Act.'

This legislation follows upon several unsuccessful attempts over the last 15 years $^{2}$ to reform the principal provisions of Canada's competition law dealing with mergers, monopolization and conspiracies in restraint of trade.

Its main elements are the result of substantial consultation with the business community, consumer interests and provincial governments. The legislation reflects a conscious effort to take into account the main features of the Canadian economy: relatively small domestic market size, substantial public sector ownership of commercial enterprises, relatively high concentration in some sectors and increasing dependence on international trade.

The Competition Act represents one of the major economic policy initiatives of the present Conservative Government. It is significant that revision of the competition law followed the revision of Canada's foreign

- Partner, Fraser \& Beatty, Ottawa, Ontario.

** Associate, Fraser \& Beatty, Ottawa, Ontario.

1. The Competition Tribunal Act and the Competition Act, S.C. 1986, c. 26, were proclaimed in force (except s. 47 enacting Part VIII of the latter Act) on 19 June 1986 by SI/86-109. Part VIII (ss. 80 to 96) of the Competition Act had not been proclaimed in force to the time of writing in June 1987. The Combines Investigation Act, R.S.C. 1970, c. C-23, as am. S.C. 1974-75-76, c. 76 and S.C. $1976-77$, c. 28 , is referred to herein as the Combines Act. It was renamed the Competition Act by S.C. 1986, c. 26, s. 19, and, accordingly, the current statutory provisions are referred to herein as the Competition Act.

2. In 1969, a Report of the Economic Council of Canada on the subject of competition policy identified the need for substantial reforms to the Combines Act. Among the changes recommended were the shifting of merger and monopoly (abuse of dominant position) from criminal to civil law, and the creation of a specialized administrative tribunal to adjudicate civil matters.

In 1976, the Combines Act was amended (S.C. 1974-75-76, c. 76), primarily to provide civil remedies against certain "non-price" restraints against trade and to extend the Act to services. The more substantial and controversial proposals were essentially left untouched by these proposals.

Prior to the 1986 Bill C-91, attempts to reform the merger and monopoly law were made in 1971 (Bill C-256), 1977 (Bill C-42), 1977-1979 (Bill C-13) and 1984 (Bill C-29), all of which died on the Order Paper. 
investment law in what forms a rather lengthy list of priority revisions to "framework" legislation which includes, as well, amendments to patent, copyright and bankruptcy legislation.

This paper will examine the areas where the changes to Canada's competition law have been most significant, under the following headings:

- Shift to Civil Law

- Merger Law

- Pre-Notification of Certain Transactions

- Abuse of Dominant Position

- The Competition Tribunal

- Conspiracy in Restraint of Trade

- Other Matters

\section{SHIFT TO CIVIL LAW}

Consistent with previous efforts at revision, the amendments recognized that a basic weakness of Canadian competition law had been the assessment of complex economic activities, and the impacts of mergers and the exercise of market power, in a criminal law setting. Compared to civil process, criminal process had been shown to be too inflexible and too timeconsuming. The criminal standard of proof of "beyond a reasonable doubt" had made it virtually impossible for the government to succeed in cases which, of necessity, were built largely on circumstantial evidence and expert predictions of the results of commercial activity. Finally, criminal sanctions were clearly inappropriate and ineffective in achieving Parliament's objective of maintaining or restoring competition.

With the shift to civil law, businesses should expect the Director of Investigation and Research (the federal government official responsible for administering the Competition Act) to take action in situations which may not have caused it concern under the Combines Act. For example, the market share threshold which may now activate a merger inquiry is likely to be closer to $50 \%$ compared to the situation of "virtual monopoly" (e.g. $80 \%$ to $90 \%$ ) dictated by case law under the Combines Act. The civil law standard of proof of "on a balance of probabilities", and the likelihood of more liberal rules on the admissibility and weighing of opinion evidence on the part of the Competition Tribunal, are likely to lead to considerable innovation in the evidence employed in competition matters, particularly expert economic evidence adduced by the Director.

The civil process employed by the Competition Tribunal in merger and abuse of dominant position matters should also afford the Director greater incentive and scope to arrive at negotiated out-of-court settlements (known as "consent decrees" in U.S. anti-trust law) which would form the basis of an agreement not to pursue an inquiry or an order by the Tribunal which either stays or decides an application from the Director.

Given the closeness of the tests under the new civil merger and monopolization (abuse of dominant position) regimes to United States law and the fact that U.S. anti-trust law is also civil, U.S. anti-trust jurisprudence can be expected to take on increasing relevance to business planners, legal counsel and government officials in addressing Canadian competition law issues. 


\section{MERGER LAW}

From a business perspective, the most important amendments are those dealing with mergers.

The Combines Act created a criminal offence in the acquisition of control "whereby competition ... is or is likely to be lessened to the detriment or against the interest of the public". ${ }^{3}$ This prohibition resulted in only eight prosecutions and no contested convictions over 75 years. It has been repealed and replaced by new civil law provisions. ${ }^{4}$

Under the new Act, the Competition Tribunal may prohibit a proposed merger or dissolve a consummated merger if it finds that the merger "prevents or lessens, or is likely to prevent or lessen, competition substantially". This test is similar to the test employed in the U.S. and Japan. Section 65 lists a number of factors (derived from the economics literature) which may be considered by the Competition Tribunal in reaching its decision:

- the extent of foreign competition faced by the merging parties;

- whether the business of one of the parties has failed or is likely to fail;

- the extent to which acceptable substitutes for the products of the merging parties are or are likely to become available;

- the effect of any barriers to entry into a market (including tariff and non-tariff barriers to international trade, interprovincial barriers to trade, and regulatory controls over entry);

- the extent of effective competition remaining post-merger; and

- the likelihood the merger will or would result in the removal of a vigorous and effective competitor.

This list is not exhaustive; all factors relevant to the impact of the merger on competition may be considered. The listed factors are intended to provide guidance to both business and the Director in applying the Act and to improve the justiciability of issues before the Competition Tribunal.

The Act makes it clear that the Tribunal may not find that a merger would substantially lessen competition solely on the basis of evidence of concentration or market share..$^{5}$ This provision is designed to ensure that persuasive qualitative and quantitative evidence which recognizes the dynamics of competition is presented.

There are two important exceptions to the authority of the Tribunal to prohibit a merger. First, the Tribunal may not make an order if it finds that the merger will result in gains in efficiency that will be greater than, and will offset, the effects of any lessening of competition flowing from the merger. ${ }^{6}$ In assessing this issue, the Tribunal is required to consider whether the efficiency gain will result in a significant increase in the real value of exports or a significant substitution of domestic products for imported products. The most likely efficiency gains to be considered are those

3. Combines Act, supra n. 1, s. 33 and definition of "merger" in s. 2.

4. Competition Act, supra n. 1, ss. 64 to 72.

5. Id. at subs. 64(2).

6. Id. at subs. 68(1). 
associated with economies of scale or scope. The section makes it clear that pure distributional effects should not be regarded as efficiency gains.

It is not yet clear, however, whether the Competition Tribunal will take into account efficiency gains that may occur without a merger, such as improved management or cost control, or whether the Tribunal will confine the efficiency defence to gains which can only be realized by a merger (e.g. scale and scope economies, productivity improvements from the transfer of proprietary technology). Nor is it clear whether the Tribunal will regard increased exports or import substitution as conclusive evidence of efficiency gains, or merely as some relevant, but not determining, evidence of such gains.

Even consideration of traditional efficiency gains arising from greater plant specialization and longer production runs, as is often a merger goal where essentially similar facilities such as refineries are owned by each party, may pose difficult technical issues:

- To what extent are plant engineering attributes comparable or distinctive?

- What are the future demand projections for the products in question?

- How will plant specialization affect total costs of serving the relevant geographic market?

- What is the relevant measure for calculating product costs (incremental or fully distributed costs), especially if there is an over-capacity situation in the industry?

- How would proposed plant closings or divestitures be incorporated into assessing efficiency changes?

The second exemption relates to joint ventures. Joint ventures have proven to be an important risk sharing vehicle in resource exploration and development in Canada. In an effort to avoid a chilling effect on their use, the Act prevents the Tribunal from prohibiting joint ventures which are formed to undertake a specific project or program of research and development if a number of criteria are met. ${ }^{7}$

The most important criterion is that the project or program would not otherwise have been undertaken. Two separate tests apply. The first and more general test is that the project or program would not have taken place or be likely to have taken place in the absence of the combination. ${ }^{8}$ Because this test left room to argue that relatively small resource developments might still have been absorbed by a single large firm given its assets and overall capital attraction capacity, a second narrower test was also introduced after consultation with the oil and gas industry. This test exempts joint ventures where the project or program would not reasonably have taken place or reasonably be likely to take place in the absence of the combination because of the risks involved in relation to the project or program and the business to which it relates. ${ }^{9}$ When read together with the general test, the second test would appear to permit firms to obtain a joint

7. Id. at subs. 67(1).

8. Id. at subpara. 67(1) (a) (i).

9. Id. at subpara. 67(1) (a) (ii). 
venture exemption for small but particularly high risk or specialized projects.

In addition to meeting the "specific project or program of research and development" and the "but for" tests, the following criteria must also all be satisfied: ${ }^{10}$

- no change of control results among the co-venturers;

- the co-venturers are governed by a written agreement which imposes an obligation on one or more of them to contribute assets and which governs the relationship;

- the agreement restricts the range of the venture activities and provides for termination on completion of the project or program; and

- competition is lessened only to the extent necessary to undertake and complete the project or program.

While the joint venture exception is intended to increase certainty in the competition law, compliance with its numerous criteria will likely challenge business planners and their counsel. Questions which remain to be answered include: (1) How small does a project or program, relative to the market or the activities of the co-venturers, have to be in order to activate the exception? (2) What duration or certainty of completion will be required to qualify as a project or program? (3) Would mutual interlocking financial obligations providing for forfeiture of assets or indemnification by way of securities offend the condition of no change of control? (4) How much research and how much development has to occur within the project to meet the definition?

It should also be kept in mind that the joint venture exemption applies only to an order by the Tribinal and not an investigation or an application to the Tribunal by the Director of Investigation and Research. It therefore leaves scope for intervention by the Director in joint ventures with a view to negotiating a different arrangement with the parties.

It must be hoped that, despite its litigation-inviting detail and complexity, a pragmatic approach will be taken by the competition authorities towards joint ventures and combinations whose design follows established industry norms, which do develop new resources or lines of business, or which are structured to terminate at a reasonably ascertainable time. A broad interpretation of the many exemption criteria by the competition authorities could well have a chilling effect on innovative business structures.

Many of the substantive standards of the new merger provisions are couched in economic language and it may prove difficult for the Tribunal to give practical application to this fairly theoretical terminology. Contested applications before the Tribunal are likely to be waged in large part with economics experts - an eventuality which many businessmen would not be pleased to encounter.

As well, parties in a contested application also run the risk that the proceeding may be politicized through one or more interventions by

10. Id. at subs. 67(1). 
provincial Attorneys General for which the Act now provides, " a factor which should especially be kept in mind by proven politically sensitive industries such as the oil and gas industry. An added factor for the oil and gas industry is the cleavage of interests between energy-producing and energy-consuming provinces. Virtually any major structural, price, or policy change in the industry that may be brought to the Competition Tribunal is, therefore, likely to attract critical attention from a major province or regional grouping representing either the pro-consumer or pro-producer perspective.

Uncertainties arising from the merger criteria and the hearing process can be alleviated somewhat by the ability of merging parties to obtain an advance clearance certificate from the Director indicating that he would not have sufficient grounds to make an application to the Tribunal..$^{12}$

In some cases, the issuance of a clearance certificate will become the focus for negotiation between the Director and the merging parties on an out-of-court settlement containing undertakings or conditions which satisfy the Director that the merger will not result in a substantial lessening of competition.

There is, however, little incentive for the Director to grant a clearance certificate save in the clearest and easiest cases. The Director loses nothing in not doing so. Often it will appear that the option of attacking the merger should be retained because facts may change or because the less than perfect information at hand permits a less than perfect assessment of the merger.

Parties approaching the Director for a clearance certificate should be prepared to provide detailed information on industry structure, business plans and markets in order to assist the Director in making a determination. This approach, therefore, entails risks, as there is no obligation on the Director not to use this information in a formal application for an order not to proceed in this manner, should he elect to do so.

Difficult questions regarding the application of the merger law and the "efficiency defence" are likely to arise for relatively stable industries where at present no single firm would appear to be in a dominant position, such as petroleum product refining and distribution, where a merger between large firms may arguably give rise to a single dominant firm. In the United States, such mergers have been attacked on the grounds that the merger would facilitate inter-firm co-ordination and reduce competition and/or lead to anti-competitive dominant firm behaviour. As a result, U.S. authorities have sought an "ounce of prevention" within the merger to establish competition rules for the future behaviour of the merged firm.

\section{PRE-NOTIFICATION OF CERTAIN TRANSACTIONS}

The Competition Act establishes, for the first time, a compulsory prenotification requirement for certain transactions. ${ }^{13}$ Similar requirements

11. Id. at s. 73 .

12. Id. at s. 74.

13. Supra n. 1. Proclamation of Part VIII (ss. 80 to 96 ) is planned for July 1987 and will be coincident with the adoption of the proposed Notifiable Transactions Regulations. These proposed Regulations were published for public comment (a requirement under the Act) in the Canada Gazette Part I of 14 March, 1987. 
already exist in the merger laws of the United States, Japan, West Germany and Australia.

The pre-notification requirements are designed to apply to only a relatively small number of mergers that are likely to have an adverse effect on competition, which would probably have been subject to some investigation by the Director in any event.

The objective of pre-notification is to increase the effectiveness of the new merger law by creating a greater opportunity for the government to obtain a prospective rather than an after-the-fact remedy, or, simply put, to avoid having to "unscramble the eggs" in order to prevent a merger having an adverse effect on competition. From a business perspective, the possibility of pre-notification creates an additional factor to build into an acquisition strategy. However, this price may, in some instances, be offset by the possible benefit of reduced risk that the Director will challenge a transaction after it has gone beyond the point of no return where considerable expense must be absorbed by the parties to undo, alter, or delay the deal.

The classes of transactions which must be pre-notified are share or asset acquisitions, amalgamations, and combinations or joint ventures. It is presumed that all three classes of transactions fall within the definition of merger used in the Act, although the term "merger" is not used in the prenotification sections. Arguably, however, the definition of merger, as it centres on the acquisition of control or significant interest, ${ }^{14}$ covers a broader range of transactions than the pre-notification provisions, for example, the issuance of a significant debt instrument to a competitor subject to conditions which constrain the decision-making freedom of the management of the issuing company.

It is important to note subsection 85(c) of the Act. This subsection creates a general exemption from the pre-notification section for transactions pursuant to an agreement entered into before Part VIII is in force, provided the transaction is substantially completed within one year of the section coming into force. This exemption would appear to mean that parties who have entered into an agreement (one wonders if a letter of intent would be sufficient) to buy assets, for example, could escape the prenotification rules even if the transaction did not close for one year. Of course, the substantive merger rules would still apply to the transaction, since they capture all mergers not "substantially completed" by June 19, 1986.

\section{A. THRESHOLDS}

The Director must be notified of any transaction which exceeds certain thresholds specified in the Act within the applicable statutory notice period, up to 21 days prior to the completion of the transaction. Two thresholds must be satisfied: party size and transaction size. First, the parties to the transaction and their affiliates must have assets or annual sales in Canada which exceed $\$ 400$ million. ${ }^{\text {s }}$ Differing transaction thresh-

14. Competition Act, supra n. 1, s. 63.

15. Id. at subs. 81(1). 
olds apply depending on the transaction method employed. For asset or share acquisitions, the assets or annual revenues from assets of the business to be acquired must be greater than $\$ 35$ million. ${ }^{16}$ For amalgamations, the assets or annual revenues of the amalgamated company must exceed $\$ 70$ million. ${ }^{17}$ For combinations or joint ventures, the threshold is $\$ 35$ million in assets or annual revenues of the combined business. ${ }^{18}$

These threshold values all refer to assets or revenues in Canada. Calculating Canada-specific values may present difficulties for some businesses operating internationally, whether their operations are found solely in Canada or whether their operations are spread among Canada and other countries.

Some assistance on valuation questions may be provided by the proposed Notifiable Transactions Regulations. These Regulations rely on valuation definitions based on generally accepted accounting practices and information which the government expects to be readily available to parties to major acquisitions. Net book value has been proposed as the standard for determining "aggregate value" for the purpose of prenotification. In most cases, gross revenues from sales would be derived from the most recent audited financial statements of the parties.

\section{B. TIME PERIODS}

The Act requires the acquiring party only to notify the Director 7 or 21 days prior to the completion of a transaction that exceeds a threshold. This is purely a notice; approval of the Director or the Competition Tribunal is not required before completing the transaction. Unlike the U.S. rules, the acquired party does not have to file a notice.

The selection of the time period is at the option of the acquiring party. ${ }^{19}$ The initial information requirements under the seven-day period (which is intended for transactions which have little or no impact on competition) are less onerous. However, the acquiring party does run the risk that the Director will require more information. If so, the Director can notify the acquiring party that the 21-day period will apply and thereby require the more detailed filing applicable to such a notice.

16. Id. at subs. 82(2) and (3).

17. Id. at subs. 82(4).

18. Id. at subs. $82(5)$.

19. Id. at s. 92. 


\section{INFORMATION REQUIREMENTS}

The pre-notification requirements are spelled out in detail in the Act. ${ }^{20}$ They are less detailed than under the U.S. Hart-Scott-Rodino Act Rules, ${ }^{21}$ but will still place a significant administrative burden on parties in the midst of an acquisition process, particularly where equivalent information from affiliates is needed.

A further complication is that the acquiring party must provide the information on the acquired party. As this may be prohibitively difficult in some situations, the Act allows the acquiring party, where the information is not known or reasonably available, to inform the Director which information is not being provided and why. ${ }^{22}$ The provision also covers information which cannot be obtained without breaching a confidentiality requirement established by law or without creating a significant risk that confidential information will be used for an improper purpose or be disclosed to the public.

Information may be withheld on the ground that it is irrelevant to the Director's assessment of the transaction's effect on competition. ${ }^{23}$ The Director can, nevertheless, require the provision of this information within seven days. ${ }^{24}$

As the information to be supplied includes a description of the transaction, the business objectives intended to be achieved, line of business information (including affiliates with "significant assets" in Canada), and information on suppliers and customers, there is considerable room to test the scope of the provision. Further, the pure logistical considerations in ensuring that this information is available to the acquiring party in a useful form (which allows comparisons of the lines of business of both parties) will become a major factor in putting together a merger and timing its announcement and implementation.

\section{EXEMPTIONS}

There are a number of exemptions from the pre-notification requirements. All transactions between affiliated parties are exempt. ${ }^{25}$ Also

20. Id. at ss. 93 and 94.

21. Under the Hart-Scott-Rodino Anti-trust Improvements Act of 1976, 15 U.S.C. S18A (1982), parties to a merger are required to file premerger notification with the Federal Trade Commission and Justice Department if three tests are satisfied:

(1) either the acquiring person or the acquired person is engaged in interstate or foreign commerce of the United States or in any activity affecting such commerce;

(2) one party has at least $\$ 10$ million in total assets (or annual net sales if engaged in manufacturing) and the other party has at least $\$ 100$ million; and

(3) the transaction would result in the acquiring person holding at least 15 percent or $\$ 15$ million of the voting securities or assets of the acquired person.

These tests are subject to numerous qualifications and exceptions. If premerger notification is necessary, the parties cannot go forward with the merger until 30 calendar days ( 15 days in the case of a cash tender of fer) following the filing of such notification.

22. Competition Act, supra n. 1 at subs. 88(1).

23. Id. at subs. 88(2).

24. Id. at subs. 88(3).

25. Id. at para. 85(a). 
exempt are those transactions where the Director has issued an advance clearance certificate pursuant to section $74 .{ }^{26}$

Of special importance to the resource development sector is the exemption for acquisitions of voting shares of a corporation pursuant to an agreement in writing that provides for the issuance of those shares only if the person or persons acquiring them incur expenses to carry out exploration or development activities with respect to a Canadian resource property as defined in paragraph 65 (15)(c) of the Income Tax Act, in respect of which the corporation has the right to carry out those activities where the corporation does not have any significant assets other than that property. ${ }^{27}$ This exemption is meant to cover acquisitions relating to petroleum or natural gas properties, interests in properties, royalties or licenses, and mineral property or prospecting, exploration or drilling rights or royalties where the acquiror is required to incur expenses to carry out exploration or development activities with respect to such properties.

Other important exemptions related to asset or share acquisitions are: ${ }^{28}$

(a) acquisitions of real property or goods in the ordinary course of business (unless substantially all the assets of the business are acquired);

(b) acquisitions for underwriting only; and

(c) acquisitions by a creditor in the ordinary course of business.

There is also an exemption for joint ventures. The term joint venture is not defined. Rather, the term used is "combination". The exemption is available where: ${ }^{29}$

(1) all the persons who propose to form the combination are parties to an agreement in writing or intended to be put in writing that imposes on one or more of them an obligation to contribute assets and governs a continuing relationship between those parties;

(2) no change in control over any party to the combination would result from the combination; and

(3) the agreement restricts the range of activities that may be carried on pursuant to the combination, and contains provisions that would allow for its orderly termination.

The pre-notification exemption for joint ventures is more broadly cast than the criteria for exempting a joint venture from the merger law. There is no restriction to a project or program of research and development and no "but for" test. Parties to a co-venture must, therefore, keep in mind that an arrangement structured to comply with pre-notification exemption is not necessarily immune from attack under the merger law.

Finally, the Governor in Council can add to the list of exemptions. ${ }^{30}$

The pre-notification rules are by far the most technical and complicated provisions of the new Act. They will impose on the business community a significant new legal requirement to consider in future merger activity.

26. Id. at para. $85(\mathrm{~b})$.

27. Id. at para. 83(f); Income Tax Act, S.C. 1970-71-72, c. 63, as am.

28. Id. at paras. 83(a), (b) and (d) respectively.

29. Id. at s. 84.

30. Id. at para. 85(d). 


\section{ABUSE OF DOMINANT POSITION}

Civil remedies against "abuse of dominant position" have replaced criminal sanctions against the operation of a monopoly. The abuse of dominant position provision is aimed at defining the boundary between productive and anti-competitive behaviour for firms possessing substantial market power. The prescribed conduct clearly directs the competition authorities to the process of monopolization.

These amendments will likely be very important to the small business community. They establish new business planning considerations for firms which are aiming at expanding an already large market share or diversifying through vertical integration.

An abuse of dominant position may occur if a person substantially or completely controls a business in Canada (or any part thereof) and engages in a practice of anti-competitive acts, the effect being to prevent or lessen competition substantially. ${ }^{31}$

The Act defines the following, among others, as anti-competitive acts: ${ }^{32}$

(a) squeezing the margins available to an unintegrated customer by a vertically integrated and competing supplier for the purpose of impeding the customer's entry into, or expansion in, a market;

(b) acquisition by a supplier of a customer who would otherwise be available to a competitor of the supplier or the acquisition by a customer of a supplier who would otherwise be available to a competitor of the customer, for the purpose of impeding the competitor's entry into, or eliminating him from, a market;

(c) freight equalization on the plant of a competitor for the purpose of impeding or preventing his entry into, or eliminating him from, a market;

(d) use of fighting brands introduced selectively on a temporary basis to discipline or eliminate a competitor;

(e) pre-emption of scarce facilities or resources required by a competitor for the operation of a business, with the object of withholding the facilities or resources from a market; and

(f) selling articles at a price lower than the acquisition cost for the purpose of disciplining or eliminating a competitor.

The Act makes it clear that this list is illustrative and not exhaustive of the restrictive and exclusionary activities the Act is aimed at preventing.

It is worth noting that a number of the anti-competitive acts are framed in a more immediate and business-oriented manner than are the factors to be examined in determining whether a merger substantially lessens competition. They are, therefore, more likely to provide useful guidance to business planning. A large number of key terms (many of which are taken from the industrial organization economics field), however, have yet to be amplified or defined in Canadian law (for example, "fighting brands") and can be expected to be the focus of strongly conflicting views regarding their applicability to a particular fact situation.

31. Id. at s. 51 .

32. Id. at s. 50. 
It is also worth noting that a number of the illustrative anti-competitive acts address conduct of vertically integrated forms in combatting entry by specialized independent firms at various points in the marketing chain, particularly where the independent firms are also customers of products of the vertically integrated firm. This should make the abuse provisions of special relevance to integrated oil and gas companies in their dealings with specialized companies such as gasoline retailers.

The illustrative anti-competitive acts require a finding that their purpose was to impede or lessen competitive entry. This suggests that an element of anti-competitive intent must be established, at least if the Director's case is founded upon one of the listed acts ${ }^{33}$ Given the civil nature of the matter, it is arguable that the Tribunal may be entitled to infer an anti-competitive purpose from circumstantial evidence and that no direct or subjective evidence (which would be virtually impossible to obtain) of anti-competitive purpose need be led by the Director.

As well, the Director can be expected not to limit himself to the listed acts and to be guided by the general spirit of the amendments. ${ }^{34}$ Nevertheless, evidence and case theories employed by the competition authorities in a dominance case can probably be expected to be more pragmatic and understandable than in a merger case, particularly as the foundation of the Director's case is often likely to be a course of conduct directed at a particular competitor or group of competitors.

In determining whether the effect of a practice of anti-competitive acts is to prevent or lessen competition substantially, the Tribunal is required to consider whether the practice is a result of superior competitive performance ${ }^{35}$ The Tribunal is not obliged to refuse the application of the Director if it makes such a finding, although it would appear somewhat illogical to prohibit the practice if superior competitive performance by the respondent is found. In appropriate cases, however, it may still be possible, despite such a finding, for the Director to obtain a proscriptive remedy directed at controlling the anti-competitive practices of the respondent in a more general fashion.

Arguably, the defence of superior competitive performance is broader than the efficiency defence for mergers and would cover factors relating to superior management skill, foresight, or even luck: matters which economists do not recognize as aspects of economic efficiency but which can be readily attested to by businessmen.

The Tribunal's powers on finding an abuse of dominant position are considerable. The primary remedy is prohibition of the practice..$^{36}$ If, however, the Tribunal finds that a prohibition is not likely to restore competition in the market, the Tribunal may also direct any or all persons against whom an order is sought to take such action, including the

33. The amendments, unlike the draft Bill, do not require the Tribunal to find that the object of the practice of anti-competitive acts is to lessen competition.

34. The purpose of the Competition Act as stated in s. 1.1 (added by S.C. 1986, c. 26, s. 19) is, inter alia, to ensure that "small- and medium-sized enterprises have an equitable opportunity to participate in the Canadian economy".

35. Id. at subs. 51(4).

36. Id. at subs. 51(1). 
divestiture of assets or shares, as are reasonable and as are necessary to overcome the effect of the practice in that market. ${ }^{37}$

As a final point, it should be kept in mind that an abuse of dominant position may be practiced by "one or more" persons, i.e. a "joint dominance" situation. It is, therefore, possible for an order to be made against a number of firms which have adopted exclusionary practices (the legislation does not appear to require that they are identical practices) directed at impeding the entry of a certain competitor or competitors. Moreover, it is not clear that these practices must be agreed to or even consciously co-ordinated in some fashion.

The likelihood of co-ordinated exclusionary practices is arguably greatest in a market structure characterized by a few major vertically integrated firms which market highly substitutable products. These indicia are generally regarded as the most fertile for the development of effective coordinating mechanisms. They are also the characteristics of the oil and gas industry. Business planners in this industry and their legal counsel should, therefore, be particularly mindful of the joint dominance possibilities of the abuse sections, especially with respect to practices which, if undertaken by only one firm in the industry, may not be reviewable as that firm alone may not substantially or completely control the class or species of business in question.

The Director may, as a result, elect to seek an order against a joint dominance situation where there is evidence of a common practise to preclude competitive entry but the facts would not support a charge of conspiracy to lessen competition, or where he considers that, even though a criminal charge could be supported, an order from the Tribunal would be speedier and more effective in restoring competition than would a criminal proceeding or conviction.

\section{THE COMPETITION TRIBUNAL}

The major institutional change in the legislation is the creation of a new Competition Tribunal under the Competition Tribunal Act to take the place of the former Restrictive Trade Practices Commission in adjudicating all civil matters under the Competition Act. The Tribunal has been modelled closely on the Restrictive Practices Court of the United Kingdom and the Market Court of Sweden.

In addition to merger and abuse of dominant position applications, the Tribunal's jurisdiction extends to the reviewable practices established in the 1976 amendments to the Combines Act: exclusive dealing, tied selling, market restriction, refusal to deal and consignment selling. These practices deal with non-price vertical restraints to trade and are themselves recognized as manifestations of monopolizing conduct. Unlike abuse of dominant position, they do not require proof of dominance: it is sufficient that they are carried on by a major supplier or are widespread in the market. Nor is proof of an exclusionary object necessary. However, these acts are much more precisely defined than abuse of dominant position.

37. Id. at subs. 51(2). 
The Tribunal's structure reflects a deft compromise between competing interests. Consumer and small business groups advocated the creation of an expert administrative tribunal on the grounds that the courts were illequipped to assess the impact of business practices on competition and to deal with complex economics-based opinion evidence. Others supported the courts for their well-established procedures and ability to produce consistent results as well as the existence of clear and wide-ranging rights of appeal.

The Competition Tribunal is a hybrid composed of judges drawn from the Trial Division of the Federal Court and part-time lay members, both appointed by the Governor in Council for terms up to 7 years. ${ }^{38}$ The judicial members are recommended by the Minister of Justice. The lay members are recommended by the Minister of Consumer and Corporate Affairs, who is obliged to first consult with an advisory committee of representatives of business, labour and consumers. ${ }^{39}$

The judicial members alone may determine questions of law, while lay members may join in the determination of questions of fact or mixed questions of law and fact. ${ }^{40}$ Appeals lie to the Federal Court of Appeal from any decision or order of the Tribunal, as if it were a judgment of the Trial Division of the Federal Court. ${ }^{41}$ There is an automatic right of appeal on questions of law, and questions of fact may be reviewed on leave of the Federal Court of Appeal.

Unlike American competition law, only the Director may apply to the Competition Tribunal. However, any person may, with leave of the Tribunal, intervene to make representations relevant to the proceeding in respect of any matter that affects that person. ${ }^{42}$ This discretion to permit interventions is broadly cast and may provide scope to the Tribunal to allow interveners to lead evidence, cross-examine and present arguments, as is the practice before other Canadian regulatory agencies. However, it does not appear that the Act goes so far as providing interveners with standing to appeal a decision of the Tribunal.

The approach of the Tribunal to the exercise of its abundant remedial powers has been signalled in its first decision under the new merger provisions. In the Palm Dairies case, the Director applied to the Tribunal for an order which would adopt the terms of an agreement between the Director and the merging parties which, in the Director's opinion, would preclude the merger from significantly lessening competition in the market (milk products in Western Canada). The Tribunal refused the order on the grounds that it was excessively vague and complex (and, hence, would be

38. Competition Tribunal Act, supra n. 1 at s. 5 .
39. Id. at $\mathrm{s} .3$.
40. Id. at $\mathrm{s} .12$.
41. Id. at $\mathrm{s} .13$.
42. Id. at subs. $9(3)$. 
unlikely to permit effective supervision of compliance), and that perpetual monitoring by the competition authorities would likely be required. ${ }^{43}$

The Tribunal's present approach to its remedial powers can be summarized in the following excerpt from the Palm Dairies decision: ${ }^{44}$

... a consent order (or indeed any order) which the Tribunal is asked to issue should be expressed in terms sufficiently clear to permit a person governed thereby to know with tolerable certainty the extent to which conduct engaged in is either lawful or unlawful.

An appeal by the Director from the Tribunal's decision has been abandoned and the owner of Palm Dairies has announced that it is curtailing its efforts to sell the company.

\section{CONSPIRACY IN RESTRAINT OF TRADE}

The criminal law prohibition against anti-competitive agreements was retained with several modifications. The maximum fine for conviction was increased from $\$ 1$ million to $\$ 10$ million..$^{45}$

To overcome some confusion in the law arising from recent Supreme Court of Canada decisions, ${ }^{46}$ the Act now makes it clear that the courts can find the existence of an agreement or arrangement in restraint of trade from circumstantial evidence, with or without direct evidence of communication between the parties (although some evidence of communication may still be necessary if an agreement is to be proven). ${ }^{47}$

In order to facilitate greater international competitiveness, the export consortia exemptions of the conspiracy section have been broadened. Now a conviction may be obtained in the case of an export agreement among Canadian suppliers only if the agreement: ${ }^{48}$

(a) has resulted or is likely to result in a reduction or limitation of the real value of exports [previously, "volume of exports"] of a product;

43. (1986) 12 C.P.R. (3d) 540 (Competition Tribunal). The Tribunal's reasons for denying the Director's application for approval of the "consent order" in the Palm Dairies case are as follows:

By way of summary, then, the Tribunal is asked to issue a consent order which was developed through a process of negotiation between the Director and the respondents. That order will establish a highly detailed, complex and, in parts, vaguely defined arrangement between the respondents. It would require perpetual monitoring by the Director and, probably, frequent reassessment by the Tribunal. There is no evidence before the Tribunal that this complex arrangement, as opposed to a more simple straight-forward remedy such as allowing another (completely independent) purchaser to acquire Palm Dairies, is necessary to meet the objectives of the Act. Also, there is reason to doubt the effectiveness of the arrangement which it is sought to impose and consequently issuing the order could possibly lead to a substantial reduction in competition. Although the terms of the order are designed to maintain Palm as a separate competitive force in the market there is considerable doubt that they would over the long term have that result.

44. Id. at 553.

45. Combines Act, supra n. 1 at s. 32, as am. S.C. 1974-75-76, c. 76, s. 13; further am. by the Competition Act, S.C. 1986, c. 26, s. 30; the maximum fine was increased by the Competition Act, supra n. 1 at s. 32(1).

46. Most recently, Atlantic Sugar Refineries Co. Ltd. et al. v. Attorney General of Canada (1980) 54 C.C.C. (2d) 373, 16 C.R. (3d) 128, 32 N.R. 562 (S.C.C.); Aetna Insurance Company and Seventy-two Other Corporations v. The Queen (1977) 75 D.L.R. (3d) 332, 34 C.C.C. (2d) 157, [1978] 1 S.C.R. 731 (S.C.C.).

47. Competition Act, supra n. 1 at subs. 32(1.2) and (1.3).

48. Id. at paras. 32(5) (a), (b), and (c). 
(b) has restricted or is likely to restrict any person from entering into or expanding the business of exporting products from Canada; or

(c) has prevented or is likely to prevent or lessen competition unduly in the supply of services facilitating the export of products from Canada.

Section 32(5)(d) of the Combines Act, which disallowed the export exemption if an agreement lessens competition unduly in relation to a product in the domestic market, has been repealed. The objective is to clarify that unintended, ancillary effects of export agreements in the domestic market do not of fend the conspiracy prohibition.

However, it must be kept in mind that the exemption applies only to agreements relating exclusively to the export of products from Canada.

The revised conspiracy provisions and the export agreement exemption should be read carefully with new civil provisions relating to specialization agreements. ${ }^{49}$ The Competition Act recognizes that specialization agreements can improve the efficiency of Canadian industries and their export potential by permitting individual firms to realize greater economies of scale in production, marketing, and distribution. The Act provides that specialization agreements are exempted from the conspiracy and exclusive dealing provisions of the Act provided they are approved by and registered with the Tribunal.

The Tribunal must, however, find that the agreement is likely to bring efficiency gains that more than offset the effects of any lessening of competition and that no attempt has been made to coerce any person to become a party to the agreement. ${ }^{30} \mathrm{~A}$ registrable specialization agreement is also restricted to an agreement under which the parties mutually agree to discontinue producing a product each is producing at the time of the agreement. Agreements to forebear producing products not in production at the time of the agreement appear not to be covered.

The reward of approval and registration of a specialization agreement clearly carries risk. The onus would appear to be on the applicants (the parties) and the Director has a right to be heard. The approval process may require disclosure of sensitive information to the Tribunal and the Director which could seriously damage the parties if it became public. An opportunity is created for the Director to negotiate a "tighter" more "procompetitive" agreement. Should the parties fail to persuade the Tribunal that the agreement should be registered, they clearly risk an inquiry by the Director under the exclusive dealing and conspiracy provisions, with the Director starting from a superior level of knowledge than would otherwise occur.

\section{OTHER MATTERS}

Before concluding this overview, it would be worth considering briefly three other areas which have implications for the oil and gas industry.

49. Id. at ss. 57 to 62 .

50. Id. at subs. 58(1). 


\section{A. CROWN CORPORATIONS}

The scope of the competition law has been extended by clearly making the Act binding on federal and provincial Crown Corporations which are Crown Agents in respect of their competitive commercial operations. ${ }^{31}$ This change clearly puts Crown-owned oil and gas firms on the same footing as private sector firms with respect to the competition law.

\section{B. INVESTIGATORY POWERS}

The range of investigatory powers available to the Director has been recast to conform to Charter of Rights and Freedoms ${ }^{32}$ jurisprudence on safeguards against unreasonable search and seizure, and to be more consistent with the increased civil law underpinnings of the legislation. Search and seizure powers are more restricted and parallel those of the Income Tax Act..$^{33}$ Special provisions have been adopted to provide access to computer records. Other investigation techniques available include a power of the court upon application by the Director to order hearings before a presiding officer, to order the production of documents and to require returns of information under oath. ${ }^{54}$

A new investigative power is available under the amended Act that was not available under the former law - the power to order the production of records being held by an affiliate of a corporation subject to an inquiry whether the affiliate is located in Canada or outside Canada. This may prove to be a controversial amendment. The provision is similar to the new rule in the Ontario Rules of Civil Procedure for obtaining discovery from affiliates of a corporation. It marks the first effort to establish an extraterritorial reach for Canada's competition law and should be kept in mind by Canadian affiliates of "multi-national" petroleum companies and their parents.

A code for dealing with documents subject to a claim of solicitor-client priviledge has also been adopted. ${ }^{5 s}$

\section{REGULATED CONDUCT EXEMPTION}

Action which offends the Competition Act but which is authorized or required under valid federal or provincial legislation may continue to be exempt at common law from the application of the Act. The scope of this so-called regulated conduct exemption may, however, be tested further by the Director and may over time be narrowed. It is arguable that, with the constitutional basis of Canada's competition law having been shifted from the federal criminal to the federal trade and commerce power and the Competition Act having become more clearly an economic regulation law, there is new room for the courts to examine the question of paramountcy between the Competition Act and other economic regulation legislation, particularly where those laws leave a discretion to act either consistently or inconsistently with the Competition Act.

51. Id. at s. 2.1.

52. The Constitution Act, 1982, Schedule B to the Canada Act 1982, (U.K.) 1982, c. 11.

53. Supra n. 27.

54. Competition Act, supra n. 1 at s. 9.

55. Id. at s. 17. 


\section{CONCLUSION}

Mention has already been made of the special treatment accorded joint ventures under the new merger and pre-notification law. These provisions demonstrate that the drafters of the Competition Act were sensitive to the particular business needs of oil and gas exploration and development and did not want the new competition law to become an unreasonable additional regulatory burden on the industry. Still, as indicated, the joint venture provisions leave considerable room for interpretation, negotiation and possibly litigation on their scope.

The competition law issues which might arise with respect to subsequent stages of the oil and gas product production and marketing chain can, to a degree, be anticipated by keeping in mind the broad features of the industry's structure:

(a) a small number of large (mostly international) firms which have integrated through the marketing chain;

(b) stable industry structure;

(c) relatively low rate of innovation and high degree of product homogeneity; and

(d) entry largely confined to specialized operations and to the retail level.

These factors suggest that the oil and gas industry should be particularly mindful of the new merger and abuse of dominant position provisions as well as the "clarified" conspiracy law.

As well, the industry has had, and will continue to have, high political visibility in recognition of the critical role of oil and gas products in modern society and the general concern over "foreign domination" of strategic Canadian industries. In fact, with the withdrawal of the federal government from the use of other policy instruments to influence industry conduct (direct regulation, taxation, and ownership), the possibility of employing more general framework legislation to serve this end in the future increases.

Notwithstanding recent government efforts to reduce intervention in the industry, and the current depression in the prices of oil and gas products, the nature of the industry virtually dictates that it will remain closely watched by governments and a candidate for future intervention, especially were a re-invigorated international cartel or a supply shortage to force prices up again. 